\title{
Culture to Serve Barometer Sustainability of North Sumatera and HANKAMNAS Development in Indonesia
}

\section{Indra Jaya}

State Islamic University of North Sumatera, Medan, Indonesia

\begin{abstract}
:
Malay culture is a unifying tool for the diversity of ethnicity, religion and strata of social life in North Sumatra. This can be traced from: (1) In terms of religious practice manifested in the form of tolerance in carrying out social life among the adherents. (2) In terms of social life, the ability of Malay culture to internalize the diversity of tribes and customs in the differences in the life of social institutions. (3) In terms of community culture, showing the characteristics of millennial generation cultural values as a social phenomenon is actually more likely to be negative. "(4) From the economic side, although Malay culture has very little influence in determining the HANKAMNAS barometer in Indonesia, but the influence Malay culture is not a factor that causes stunted development in northern Sumatra." (5) From a political standpoint, Malay Culture positively influences the political situation in North Sumatra and at the same time Cultural change by the use of social media negatively affects the political situation in North Sumatra towards the sustainability of development so that it Impacts the Declining of HANKAMNAS in Indonesia"

Keywords:

culture; barometer sustainability; HANKAMNAS
\end{abstract}

\section{Introduction}

North Sumatra is one of the provinces in Indonesia. When viewed from the social, economic, cultural and religious aspects, the province of North Sumatra can also be called a miniature of Indonesia because in it lives and develops population with a plurality of cultural and religious tribes from various religious adherents found in all provinces throughout Indonesia. With the capital of social diversity, ethnicity and religious diversity, North Sumatra still upholds the values of harmony among religious people and national unity in one unity in diversity. This diversity can be seen from the methods carried out by the people of North Sumatra both in regional development and national resilience, it is not too grandiose to say that North Sumatra is a barometer of Indonesia's HANKAMNAS level. This potential is very important for North Sumatra in the eyes of Indonesia if this condition is utilized as well as possible for implementing social, economic and cultural development in the community.

Efforts to make the socio-economic, cultural and religious harmony in a combination of multi-ethnic, multi-ethnic and multi-religious communities is not an easy job because it is closely related to the character, character, attitudes and behavior of every population in North Sumatra. This problem is the capital in the development of a country called Indonesia. When viewed from the ethnic diversity in North Sumatra, there are eight major tribes consisting of: 1) Malays, 2) Batak (Toba Batak, Karo Batak, Mandailng Batak, Simalungun Batak, and Dairi Batak), 3) Nias, 4) Javanese, 5) Minang Kabau, 6) Sundanese, 7) Aceh and 8) ethnic migrants such as Chinese, Arabic Indians and others.

In the government system, North Sumatra is more influenced by Malay culture. If Malay culture is associated with several things such as economic, political, social, cultural and religious systems, the Malay community plays a key role in implementing the wheels of 
government in North Sumatra. This is evident from the individuals who occupy the top leadership of North Sumatra and its capital, which is led by individuals who come from the Malay tribe, namely: Dr. H. Tengku Herry Nuradi, MM as Governor of North Sumatra Province and Drs. H. Tengku Eldin, MM, M.Sc as the Mayor of Medan which is the capital of North Sumatra Province.

There is the most important thing which is a fundamental question why North Sumatra which incidentally has a diversity of cultural and religious tribes still maintained harmony in society and made North Sumatra a Security Barometer in Indonesia. This situation raises two hypotheses as follows: (1) Whether social, economic, cultural and religious harmony is influenced by Malay culture found in Sumatra (2) what determinants are sustainable social, economic, cultural and religious development in North Sumatra HANKAMNAS barometer for Indonesia

Based on the background description and research framework offered previously, this study critically examines the DETERMINATION OF THE GUARANTEE OF THE NORTH SUMATERA AS A HAMBAMNAS BAROMETER IN INDONESIA as a basis for preparing the positive consequences of high levels of dynamism, competitiveness, and social creativity that can be developed and utilized for the basic development in North Sumatra.

\section{Review of Literature}

\subsection{Malay Culture}

According to Lah Husni, customs on ethnic Malay are covered in four types, namely: (1) true customary tradition; (2) customary practices; (3) traditional customs, and (4) customs: (1) Customary tradition is if according to time and condition, if it is reduced, it will damage, if it is exceeded, it will be wasteful. This process is based on: (a) the conscience of the wise man, reflected in customary teachings: Golden bananas carry yachts; Cook a grain in a crate; Gold debt can be paid; A debt of gratitude is brought to death. (b) truly sincere truth, based on: doing because God is not because of doing; (c) commensurate decisions, based on: leaning on the back of a bunch of bananas, huddled together, eaten together.

(2) The custom which is adopted is that the custom operates on a certain foundation, according to the consensus of the inhabitants of the area then the implementation is handed over by the people to those they trust. As the adat holder is a king or prince. The implementation of this custom is for the happiness of the population, both physically and mentally, the world and the hereafter, at that time and in the future. Each country has a different situation from other countries, different depths of fish, different fields of grasslands. Differences in the conditions, places and progress of a country bring its own customs and customs, which are in accordance with the wishes of its people, inherited from their ancestors. The difference is only in its birth, not in its essence. This mandated custom is something which has been accepted to be a habit or regulation that is made together with consensus according to appropriate and correct size, which can be modified in such a flexible manner. The basis of these traditional customs is: full, not abundant, containing no less, floating not drifting, submerged not wet (Lah Husni 1986: 62).

(3) The most populous customs are habits that gradually or quickly become customary. In accordance with broken: once the flood, once the bank moved, once the age circulated, once the custom ranged. despite the change in adat, the core of adat will not 
disappear: the custom of ups and downs, the custom of hot fire, in a balanced movement, between morals and knowledge. The changes only occur in the form of variety, not in the original and original purpose. For example, if people used to use a skull or headband in an event, then now they wear kupiah to be the most populous clothing. If it used to be run-down or accompanied by accompaniment, now it's no longer. If in the past only the king could use yellow, now anyone can use it (Lah Husni 1986: 62).

(4) Customs are a collection of various customs, which are understood to be more focused on special ceremonies such as custom: marriage, coronation of the king, and the burial of the king, sea herbs, Syafar bathing, fresh flour, mulal nukal, mulaka ngebah, gebik, etc. -Other, every ceremony in Malay culture always involves elements of traditional performing arts and poetry, such as pantun, gurindam, nazam, and others. Other meanings, if the term is used only adat, then the tendency of understanding is as a set of laws, for example: customary law, human rights, etc. The four categories of Malay customs above, are the essence of Malay culture in general. Adat gives direction to all Malays to fill their lives, and direct themselves in the world and the hereafter. Adat is a set of rules, norms, and value systems that serve as a guide in life, and functions to achieve the integration and internal consistency of Malay culture.

\subsection{Social Change}

Social change as social changes that occur in the structure and function of society. A similar view was expressed by Wilbert Moore who views social change as a change in social structure, behavior patterns and social interaction. Meanwhile, according to Mac Iver, social change is a change that occurs in social relationships or as a change in balance (Robert $\mathrm{H}$. Laurer, 1993: 289).

According to Ogburn (1964: 57) Factors Influencing the Path of Social Change can be explained as follows: 1) Contact with other cultures, 2) Advanced Formal Education System, 3) Attitude of respect for one's work and the desire to progress, 4) Tolerance towards actions deviant deeds which are not delicts, 5) Open systems in layers of society, 6) Heterogeneous population, 7) Society dissatisfaction with certain fields, 8) Orientation to the future, 9) Value that humans must always endeavor to improve his life.

\subsection{Political}

To understand Indonesia's political system, as we understand other systems, we must know several key variables. The key variables in understanding a system are structure, functions, actors, values, norms, goals, inputs, outputs, responses, and feedback. Harold (2003: 33)

Analysis of the performance of the political system often refers to the theorization prepared by David Easton. Easton's description of the political system although abstract and broad but superior in its coverage. That is, Easton's theory is able to describe the performance of a political system almost holistically and is therefore often referred to as grand theory. Easton's description is also cyclical, in the sense that as a system, the political system is seen as a living organism that fulfills its own needs, experiences input, process, output, and is returned as feedback to the input structure. The input structure then responds and returns to be input into the political system. Thus the process goes on as long as the political system still exists. The results of Easton's first stage of thinking are as follows:

Environment

\begin{tabular}{|c|c|c|c|c|}
\hline \multirow{2}{*}{\multicolumn{2}{|c|}{ Demans }} & \multirow{2}{*}{ POLITICA } & \multirow{2}{*}{ Decition } & 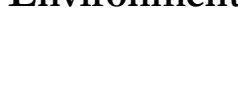 \\
\hline INPUT & & & & OUTPUT \\
\hline & Support & & Action & (2x) \\
\hline & & eedback (Umpa & Balik) & \\
\hline
\end{tabular}


Figure 1. Work Scheme of the Easton Political System (Chilcote, 1981: 147)

According to Chilcote, after revising the theory of the political system from David Easton, Almond summarized his political system's mindset into the following:

LINGKUNGAN

LINGKUNGAN

\section{PEMELIHARAAN}

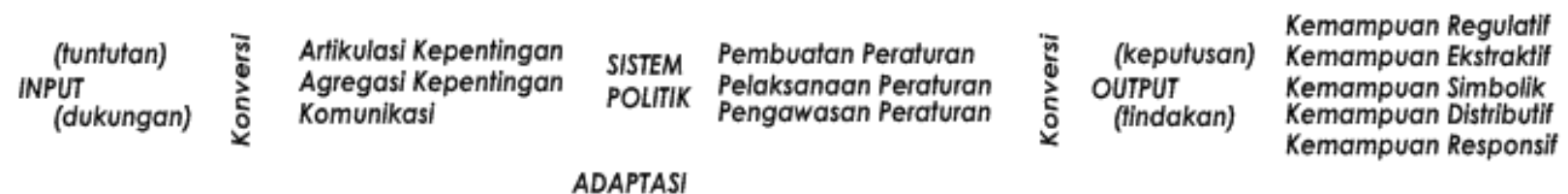

LINGKUNGAN

LINGKUNGAN

Figure 2. Diagram of Almond Political System and Functional Levels (Chilcote, 1981: 167)

\subsection{Economic Situation}

According to Gilarso (1992: 486) the economic system is the overall procedure for coordinating the behavior of the community (consumers, producers, governments, banks, etc.) in carrying out economic activities (production, distribution, consumption, investment, etc.) so that it becomes a single unit which is orderly and dynamic, and chaos can be avoided. The economy of North Sumatra as quoted from: BPS of North Sumatra Province, DJPBN, BAPPEDA, BPKAD on the Regional Economic and Financial Study of North Sumatra Province in August 2017 as follows:

\section{Regional Macroeconomic Assessment}

North Sumatra's economic growth in the second quarter of 2017 grew by $5.09 \%$ (yoy), sharply increasing compared to the previous quarter which was $4.50 \%$. These conditions indicate that the economy of North Sumatra is still quite strong. This was mainly driven by increased investment amid slowing domestic demand. However, domestic demand is still growing high and is a major driver of economic growth in North Sumatra. Investment activities related to the improved performance of the processing industry responded to the increase in foreign exports, especially CPO commodities. Meanwhile, consumption is still quite solid in line with the increase in public income due to THR, export receipts and the 14th salary. Sectorally, the performance of 4 main sectors (agriculture, processing industry, trade, and construction) in the second quarter of 2017 tends to increase. This increase was mainly driven by improvement in the performance of the agricultural sector, especially the plantation subsector. The peak of the palm oil harvest which fell in the second quarter of 2017 and the improvement in world demand and positive CPO price growth has supported the performance of the plantation subsector, especially oil palm. The improvement in the plantation subsector has boosted the performance of the manufacturing industry sector.

\section{Regional Financial Assessment}


In accordance with the pattern, the North Sumatra Province's fiscal expenditure, financed by both the Provincial and Regency / City APBDs, experienced a slight increase even though the absorption was not optimal reaching $33.7 \%$ of the ceiling or lower than the same period in the previous year which reached $55.3 \%$ It is estimated that the realization of the regional government budget will be carried out in the third and fourth quarters of 2017 , although it is still overshadowed by the risk of delays in the distribution of DAU to regions with low expenditure realization.

\section{Inflation Assessment}

The improving economic growth in North Sumatra in the second quarter of 2017 was accompanied by controlled inflationary pressures. CPI inflation in the second quarter of 2017 was recorded at $3.75 \%$, down from the first quarter of 2017 amounted to $3.91 \%$. This achievement was also below national inflation which reached $4.4 \%$. The low achievement of inflation was mainly driven by improved food supplies, which led to a quite deep decline in food prices compared to 2016. With these achievements, inflation in the North Sumatra calendar year only reached $-0.43 \%$. With this development and July 2017 inflation that is still experiencing deflation, 2017 inflation is estimated to be within the inflation target range of $4 \pm$ $1 \%$. Meanwhile, core inflationary pressures were also relatively reduced, supported by the appreciation of the exchange rate amid the level of community income which was still pressured by the decline in plantation commodity prices. Nevertheless, the level of public optimism in realizing their consumption activities is still quite good, which is reflected in the Consumer Confidence Index which tends to increase. On the other hand, administered prices inflationary pressure tends to hold deeper the decline in inflationary pressures. Administered prices inflation pressures tended to increase due to the adjustment of several commodities regulated by the government. In general, the low level of inflation has stimulated optimism for 2017 inflation that is estimated to be within the national inflation target of $4 \pm 1 \%$. Nevertheless, it is still worth watching out for inflation risks associated with rising inflationary pressures from the administered prices side related to the planned one-fuel price adjustment plan.

\subsection{Religion Experience}

Sumardi, (1985: 75) Religion is the most sublime concern of humans revealed as the answer to the call of the Almighty and the Eternal. This sublime concern is expressed in human life, individuals or groups towards God, towards humans and towards the universe and its contents. " Geertz (1992: 13) argues that revelation forms a psychological structure in the human mind that forms a view of life, which becomes a means of individuals or groups of individuals who direct their behavior. But also revelation not only produces immaterial culture, but also in the form of sound art, carvings, buildings.

As explained by the Governor of North Sumatra HT. Erry Nuradi to support religious harmony there must be efforts to improve the quality of religious understanding and practice. Ministry of Religion together with religious assemblies and religious leaders need to continue to foster religious communities through empowering religious instructors, empowering houses of worship, commemorating religious events, providing holy books and through other religious service activities. With these activities it is expected to foster a stronger understanding of religious attitudes. In the context of the nation's moral development, of course it cannot be separated from the various problems currently faced by the nation. From economic problems, social politics and security to issues of morality and cultural identity. Therefore, the Governor of North Sumatra invited all communities consisting of various tribes, religions, races and groups to maintain unity in the diversity. The commemoration of 
the 71st Ministry of Religion's Charity Day is also expected to be a momentum to increase the services of the Ministry of Religion, particularly in strengthening the harmony of Indonesian diverse people. (http://pelitabatak.com/news/Gubernator---Kemenag-No-Milik-Satu-Rama).

\section{Research Methods}

This study explains a practical picture based on the concept of confirmatory. The process is carried out through various patterns of cascading causality relationships in looking at the HANKAMNAS barometer in Indonesia through the sustainable development of community life in North Sumatra. The research was conducted in 2014-2016. This research was classified as a survey research with a sample of 1,200,000 respondents spread across ten regencies / cities as research sample areas, namely: Medan City, Deli Serdang Regency, Tebing Tinggi City, Madya Siantar City, Regency Langkat, Serdang Bedagai, South Nias, Coal, Labuhan Batu Utara, and Tobasa. The pattern of tiered causality referred to is, seeing the estimated direct and indirect effects (effects). The direct influence of Malay culture on social, cultural, economic, political and religious life indirectly affects the sustainability of North Sumatra development and the HAMKAMNAS barometer in Indonesia.

The analysis technique uses (Path Analysis with the Lisrel program version 9.20 of Karl G. Joreskog \& Dag Sorbon. This study involved eight variables namely: Malay cultural variables (X1), Social variables (X2), Cultural variables (X3), Economic variables ( X4), Political Variables (X5), Religious Variables (X6), Development Sustainability Variables (Y1) and HANKAMNAS Barometer Variables (Y2) The form of analytical framework offered in this study, can be seen in the following scheme :

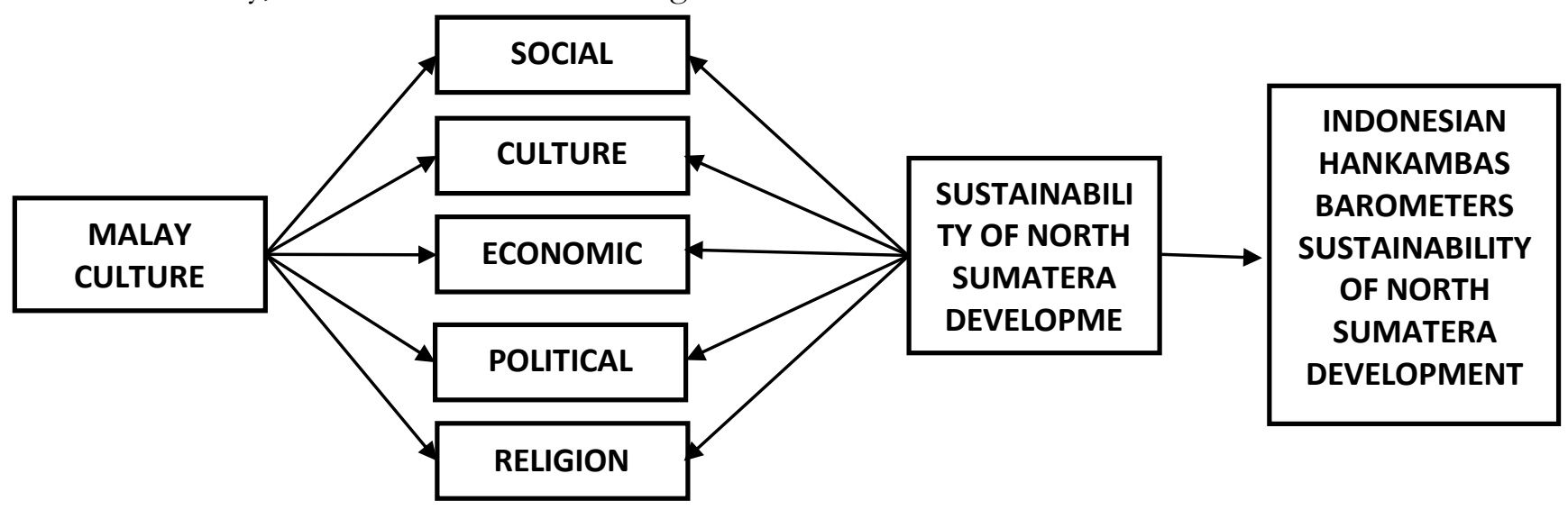

Figure 3. Research Framework

The analysis results can be shown in the following scheme: 


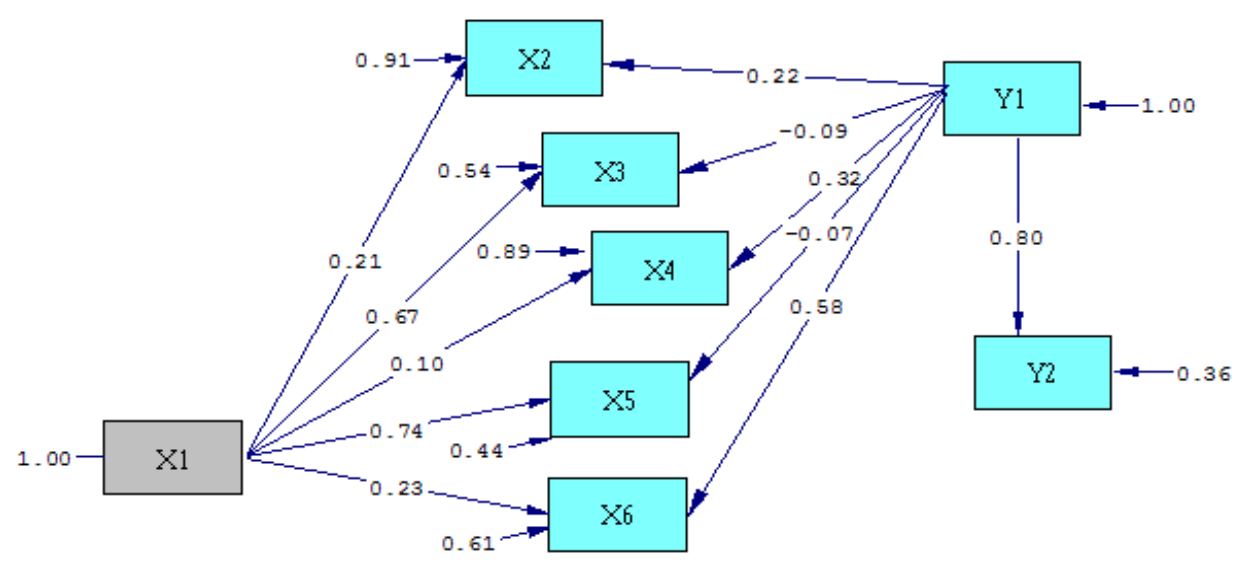

Chi-Square=1619.62, df=18, P-value=0.00000, RMSEA=0.280

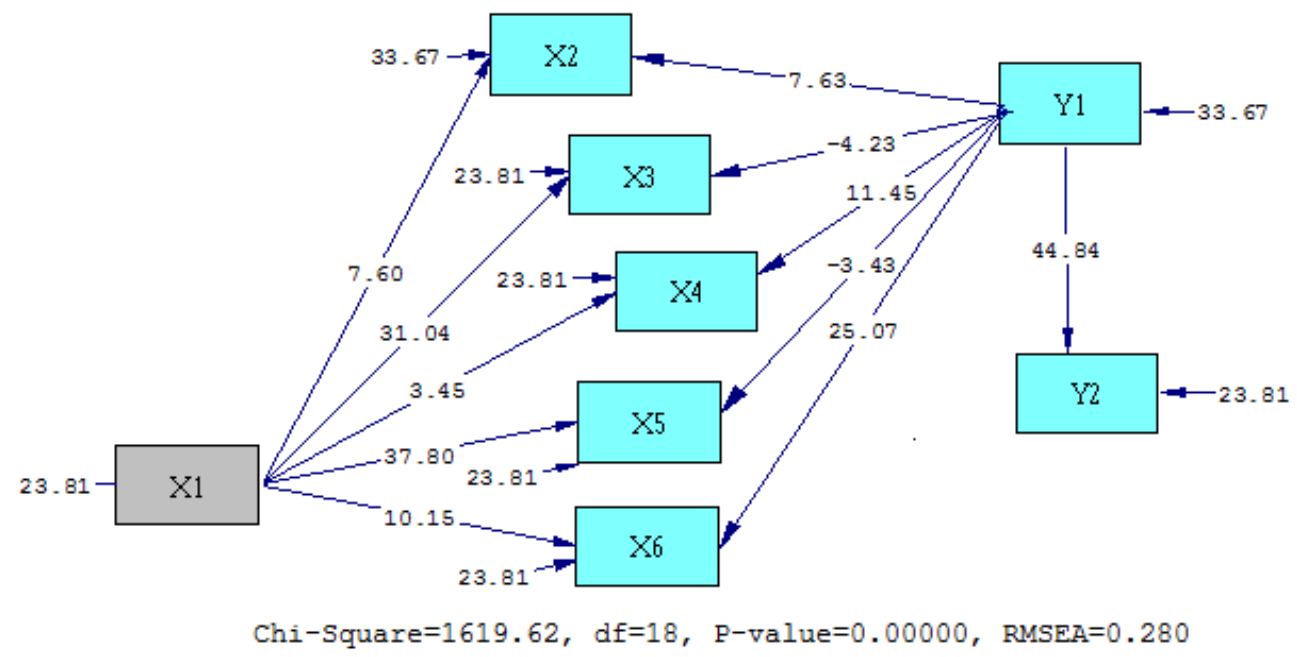

\section{Discussion}

The results of the impulse analysis found that Malay culture indirectly significantly affected HANKAMNAS Indonesia through social, cultural, economic, political and religious situations which simultaneously shaped the sustainability of development in North Sumatra by 0.80 with a $\mathrm{T}$-value of 44.84 . The magnitude of this coefficient value is enough to prove that Malay culture has a significant share in creating a sustainable development situation in North Sumatra and at the same time is a strong indicator in giving birth to HANKAMNAS in Indonesia.

If it is examined further based on the results of an impulse study it proves that the variables that shape and influence the sustainability of North Sumatra development can be explained in detail as follows:

\subsection{Religion Experience}

Religious practice factor which is realized in the form of religious harmony which is dominated by Malay society is the main factor or determinant indicator making North Sumatra has a strong foundation in ensuring the sustainability of development in North Sumatra. The results of this field finding can be proven through an impulse analysis which is shown by the coefficient that forms the sustainability of development in North Sumatra of 0.58 or $33.64 \%$ which is strengthened by the T-Values coefficient of 25.07 . Furthermore, 
statistically that this religious prediction factor was indirectly stated to be very strongly influenced by Malay culture with the coefficient of influence obtained by 0.23 or $5.29 \%$ with a significance level of the T-values coefficient of 10.15. there are other factors that influence the sustainability of development in North Sumatra by 0.61 or $37.21 \%$ which are not examined in this study with a significance level of T-Values of 23.8. If examined further the magnitude of the influence of Malay culture through the life of the community in religious practice and the sustainability of development in North Sumatra to the HAMNAS barometer in Indonesia amounted to 0.1067 or $1.13 \%$ while the rest was stated to be from other factors. The magnitude of the influence of religious practice of the people of North Sumatra for their contribution to the HAMKANAS barometer in Indonesia, indicates that the people of North Sumatra in practicing religion for each of their adherents have shown an open attitude towards other religions by means of religious literacy. As explained by Purnomo. (2003: 35) in the life of religious pluralism, religious literacy needs to be developed, that is, an open attitude towards other religions by means of religious literacy.

Based on the coefficient values described previously, it can be said that "Malay culture in North Sumatra has an influence on religious practice factors which are manifested in the form of tolerance in carrying out community life among the followers of the community expressed as very positive and significant have been able to sustain sustainable development in northern Sumatra and not immediately able to become a barometer of HANKAMNAS in Indonesia ".

The findings of this study further explained that prolonged conflicts related to diversity, especially religion, did not occur in North Sumatra due to three important points that had been maintaining such diversity and had to be preserved so that harmony was maintained. Among them, namely local wisdom, which is maintained by traditional leaders / community leaders (toma), where if there is a dispute, the traditional leaders / toma will take a role in resolving conflicts that occur with dialogue.

\subsection{Economic Situation}

Next, the determining factor in sustaining development in North Sumatara is the economic situation. The results of the analysis of the empirical prove that the economic situation contributes in shaping the sustainability of the development of North Sumatra by 0.32 or $10.24 \%$ with a $\mathrm{T}$-Values significance coefficient of 11.45 , in addition to the economic factors which are forming factors as explained earlier, it is also evident from the results of the analysis that Malay cultural factors also influence economic factors when these factors shape the sustainability of development in North Sumatra which is equal to 0.10 or equal to $1 \%$ with a coefficient of significance for T-Values of 3.45. Furthermore, the results of this analysis can be explained there are other factors or also referred to as bias factors outside of the economic and cultural factors of Malay which also contribute to shaping the sustainability of development in North Sumatra which is 0.89 or $79.21 \%$ with a T-Values coefficient of 23.81 which is stated to be very significant. The results of this analysis also prove that there is an indication of the strength of the economic situation factor in shaping the sustainability of development in North Sumatra, not because there is still strong Malay cultural interference that has existed in it, but there are large forces outside of the influence of Malay culture which underpin the power of development in North Sumatra. not examined in this study.

"Although Malay culture has very little influence in determining the HANKAMNAS barometer in Indonesia through its influence on economic factors and the sustainability of development in North Sumatra, but the influence of Malay culture is not a factor in 
hampering development in northern Sumatra". This can be proven from the indirect effect coefficient of Malay culture on the HANKAMNAS barometer in Indonesia through economic factors and the sustainability of development in North Sumatra of 0.025 or $0.065 \%$. The very small influence of this Malay culture on economic development in Sumatra and the presence of a greater bias factor has an influence on economic development in North Sumatra as the findings in this study may have had a point before, as stated by Metzger (1994: 158175). the weakness of the Malays is a lack of respect for old culture, "lazy people," and lack of curiosity.

The results of the analysis of the field findings on the economic situation in North Sumatra can be described as follows: By sector, the performance of the 4 main sectors (agriculture, manufacturing, trade and construction) in the fourth quarter of 2017 is still quite good, especially in the agriculture and construction sectors. The improvement in the performance of the agricultural sector was driven by an increase in the performance of the food agriculture and horticulture sub-sector in line with the increase in agricultural production which reached the target of 5.2 million tons or an increase of $11.0 \%$. On the other hand, the continued development of strategic infrastructure development projects has boosted the performance of the construction sector.

The simultaneous implementation of the North Sumatra Pilkada in the second quarter of 2018 also has the potential to become the main driving force of the North Sumatra economy. Amid the limited improvement in the external sector in line with falling commodity prices, the economy of North Sumatra in the first semester of 2018 is expected to experience improvement driven by domestic demand. Overall, the economy of North Sumatra in 2018 has improved and is in the range of 5.0\% - 5.4\%. This increase in growth will be driven by government consumption and LNPRT along with the implementation of 2018 local elections.

\subsection{Social Life}

Social changes that occur in the people of North Sumatra can be said to be dynamic towards a better direction. This is evident from the results of the impulse analysis that social change contributes to the sustainability of development in Sumatra by 0.22 or $4.84 \%$ with a TValues coefficient of 7.63. The magnitude of the contribution of social change in shaping the sustainability of development in North Sumatra as explained by the values of the resulting coefficients, is undeniably also positively influenced by the influence exerted by Malay culture which has long drained roots for the people in North Sumatra. This is evident from the value of the coefficient of influence given by Malay culture to the existence of social care that is equal to 0.21 or $4.41 \%$ with a T-Values coefficient of 7.60 . This means, every time a social change occurs in North Sumatra due to the influence of Malay culture to affect the sustainability of development in North Sumatra by $0.43 \%$. Furthermore, it can also be determined the magnitude of the influence of Malay culture through social life and sustainable development in North Sumatra on the HAMNAS barometer in Indonesia of 0.0369 or $0.13 \%$ while the rest is stated to be from other factors.

The results of the research have proven that "the strength of Malay culture positively and significantly influences social changes in society to be able to influence the sustainability of development in Sumatra and at the same time become a support for the HANKAMNAS barometer in Indonesia". The power of Malay culture is presumed to be the strength of the North Sumatran people in internalizing the Malay traditional religion which until now has drained the roots among the people of North Sumatra, namely: (1) True customary adat; (2) customary practices; (3) traditional customs, and (4) customs influence significantly the 
diversity of the social life of the people of North Sumatra in the form of (1) cultural contacts, (2) formal education systems, (3) attitudes of respect for one's work and the desire to progress (4) tolerance of deviant acts which are not an offense (5) open systems in layers of society, (6) heterogeneous population, (7) public dissatisfaction with certain fields, (8) future orientation, (9) efforts to improve life. These points are always indicated to accompany every social change that occurs in North Sumatra and at the same time significantly influence the diversity of the social life of the people of North Sumatra in the form of knowledge, beliefs, arts, morals, law, customs, and other habits of the community such as: institution and classification system where values, beliefs, competencies, life routines and forms of community behavior are embedded.

\subsection{Community Culture}

Nowadays, almost every family in North Sumatra society faces challenges as the entry of new values or global cultural values is often in conflict with the values of the Malay culture that has been adopted so far. Under these conditions the resilience and even survival of the Malay culture is highly dependent on the resilience of the family as the smallest unit of a North Sumatra society in the face of the current global cultural penetration. The results showed the influence of Malay culture that was adopted by the community before still making a positive contribution to cultural change in today's society of 0.67 or $44.8 \%$ with a significant coefficient value of T-Values of, but due to the current of globalization as the entry of values new values or global cultural values that are often in conflict with the values of the Malay culture adopted so far by 0.54 or by $29.16 \%$, the cultural changes that occur in North Sumatra that are believed to be able to affect negatively affect the sustainability of development in North Sumatra -0.09 or $0.81 \%$ imply this effect is stated significant or trusted with the resulting T-Values coefficient of -4.23 . If analyzed further the magnitude of the negative contribution of cultural assimilation that occurred in North Sumatra due to the current globalization through sustainable development in North Sumatra amounted to $-0,388$ or as much as $-0.15 \%$ affecting HANKAMNAS in Indonesia.

The results of the instrument study show that the presence of millennial cultural values (the generation that makes information technology a lifestyle or lifestyle) as a new phenomenon triggered by the development of information technology has a negative effect on aspects of school education and the life of individuals in the family. "The characteristics of millennial generation cultural values as social phenomena are more likely to be negative."

An interesting phenomenon in the life of Sumatran society today, the rise of global culture (global culture) and the lifestyle (life style) of pop culture. This phenomenon occurs as a result of the current of globalization that can no longer be dammed. Globalization which is often interpreted as a process of socio-economic-political and cultural system so that North Sumatra seems to be without the border (the borderless world) which is often understood as a form of uniformity, domination, and even hegemony of developed countries towards the province of North Sumatra which is developing dynamically toward the metropolitan.

Wahana (2015) stated his research results explain the increasingly declining morality of students is one result of the rapid development of technology that is not matched by improving the quality of student character, even though technological development is really needed by this nation to be able to continue to compete in the era of globalization. Moral decline is largely influenced by socio-cultural conditions in the surrounding community. The influence of cultural globalization that is not controlled and tends to be negative is a form of the lack of old cultural institutions in controlling new cultural changes in society. 


\subsection{Political Situation}

Democratic government and the same opportunity to talk politics are an interesting topic that never ends, especially in a government with a very pluralistic society as in the province of North Sumatra. Throughout the course of politics in North Sumatra to date, this survey proves that political control is still controlled by the community and holds a central position in political life in North Sumatra.

The political power of the community in determining politics in North Sumatra is very closely related to the culture of the Malay community that has been developed previously, which is very much holding the traditional values or what is called "Adat Tradition". According to Lah Husni (1986: 62) the customary tradition works on a certain foundation, according to consensus of the inhabitants of the region. then the implementation is handed over by the people to those they trust. As the adat holder is a king or prince. The implementation of this custom is for the happiness of the population, both physically and mentally, the world and the hereafter, at that time and in the future.

The implication of this customary tradition can be proven from the survey results that those who lead North Sumatra must come from North Sumatra, this was also revealed by the governor Raja Inal Siregar who had led North Sumatra in the decade 1988 to 1998 with the slogan "Marsipature Hutanabe". Apart from the motto, it is evident from the election of the governor of Sumatra that was won by the couple Edy Rahmayadi and Musa Rajekshah very clearly proven that the kemengan was caused by issues of Religion and Regionalism. This proves that the strength of North Sumatra is actually very closely related to the discussion of religious and social issues which are wrapped up by the value system in Malay culture at the time. This is evident from the influence coefficient given by the system of values contained in Malay culture on the political situation in North Sumatra of 0.67 or $44.89 \%$ with a significant level of T-Values of 31.04 as the findings of this study.

It is undeniable that there are other factors of 0.54 or $29.16 \%$ with a significant level of T-Values of 23.81 by the widespread use of social media in the community also largely determines the good and bad political situation in North Sumatra in the future and is very unfortunately the use of social media in the community is currently not controlled, this is one of the factors that causes politics in North Sumatra to be slightly disrupted until it is predicted to negatively influence the sustainability of development in North Sumatra in the future in the future -0.09 or the contribution he makes $-0.81 \%$ with a significant level of T-Values of -4.23 . If examined further the influence exerted by the factor of social media use by the community outside the contribution of the value system of Malay culture through the political situation and the continuing development in North Sumatra to the HANKAMNAS barometer in Indonesia, the contribution made was $-0,388$ or $-0.15 \%$.

Based on the previous description, it can be explained that "Malay culture positively influences the political situation in North Sumatra simultaneously. Cultural changes by the use of social media negatively affect the political situation in North Sumatra towards the sustainability of development so that it impacts on the decline of HANKAMNAS in Indonesia. 


\section{Conclusion}

1. Malay culture in North Sumatra has an influence on religious practice which is manifested in the form of tolerance in carrying out social life among the adherents of the community expressed very positive and significant has been able to sustain sustainable development in northern Sumatra and indirectly able to become a barometer of HANKAMNAS in Indonesia.

2. Although Malay culture has very little influence in determining the HANKAMNAS barometer in Indonesia through its influence on economic factors and the sustainability of development in North Sumatra, but the influence of Malay culture is not a factor in hampering development in northern Sumatra".

3. The strength of Malay culture positively and significantly influences social changes in society to be able to influence the sustainability of development in Sumatra and at the same time become a support for the HANKAMNAS barometer in Indonesia"

4. The characteristics of millennial generation cultural values as a social phenomenon in North Sumatra are more likely to negatively affect the sustainability of development in North Sumatra and impact on HANKANAS in Indonesia."

5. Malay Culture positively influences the political situation in North Sumatra simultaneously Cultural change by the use of social media negatively affects the political situation in North Sumatra towards the sustainability of development so that it Affects the Decline of HANKAMNAS in Indonesia.

\section{References}

Barker, Chris, Cultural Studies: Teori dan Praktik, Terj. Tim KUNCI Cultural Studies Centre, Bentang, 2005.

Barker, Chris. 2011. Cultural studies. Teori dan praktik. Yogyakarta : Kreasi wacana.

Budi Purnomo2003, Alays, Jakarta: Penerbit Buku Kompas,

Edgar, Andrew and Peter Sedgwick (ed.), Cultural Theory The Key Concepts, Routledge, 1999.

Geertz, Clifford. 1992, Kebudayaan dan Agama, Yogyakarta: Kanisius,

Harold D. Lasswell dikutip dalam Miriam Budiardjo, Dasar-dasar Ilmu Politik (Jakarta: Gramedia, 2003) h. 33

http://pelitabatak.com/news/Gubernur---Kemenag-Bukan-Milik-Satu-Agama

Mulyono Sumardi, Penelitian Agama, Masalah dan Pemikiran, Jakarta; Pustaka Sinar Harapan, 1982.

Robert Lauer H. 1993. Perspektif Tentang Perubahan Sosial. Jakarta: Rineka Cipta

Ronald H. Chilcote, Theories of Comparative Politics: The Search for a Paradigm, (Colorado: Westview Press, 1981)

Soekanto Soerjono. 2006. Sosiologi, Suatu Pengantar. Jakarta: Rajawali Press.

Storey, John,. 2007. Cultural Studies dan Kajian Budaya Pop, terj. Laily Rahmawati, Jalasutra

Wahana (2015) Pengaruh nilai-nilai budaya generasi millennial dan budaya sekolah terhadap ketahanan individu. Journal Ketahanan Nasional No. XXI. Halaman 14 - 22

William F.Ogburn dan Meyer F. Nimkoff: Sociology, edisi ke-4, A.Feffer and Simon International University Edition, 1964. Bagian 7 